\author{
Asian Journal of \\ Medical and Biological Research \\ ISSN 2411-4472 (Print) 2412-5571 (Online) \\ www.ebupress.com/journal/ajmbr
}

\title{
Short Communication \\ Establishment of reference ranges for Serum Leptin and C-Peptide using enzyme- linked immmunosorbent assay method: a preliminary report
}

\author{
Mainasara Abdullah Sulaiman ${ }^{1 *}$, Dahiru Shafi'u Gumel ${ }^{1}$, Umar Zayyanu Usman ${ }^{2}$, Anaja Peter Ocheni ${ }^{3}$, Yakubu \\ Abdulmumini ${ }^{4}$, Rosemary Nwaelugo Adanze ${ }^{5}$ and Yeldu Mohammed Haruna ${ }^{5}$ \\ ${ }^{1}$ Department of Chemical Pathology \& Immunology, College of Health Sciences, UDU, Sokoto-Nigeria \\ ${ }^{2}$ Department of Physiology, College of Health Sciences, UDU, Sokoto-Nigeria \\ ${ }^{3}$ Department of Chemical Pathology, Faculty of Medicine, Ahmadu Bello University, Zaria-Nigeria \\ ${ }^{4}$ Department of Medicine, Faculty of Clinical Sciences, College of Health Sciences, UDU, Sokoto-Nigeria \\ ${ }^{5}$ Department of Chemical Pathology, Ahmadu Bello University Teaching Hospital, Zaria-Nigeria \\ ${ }^{6}$ Department of Chemical Pathology, Faculty of Medical Laboratory Sciences, Usmanu Danfadioyo University, \\ Sokoto-Nigeria
}

*Corresponding author: Mainasara Abdullah Sulaiman, Department of Chemical Pathology \& Immunology, College of Health Sciences, UDU, Sokoto-Nigeria. Phone: +2348035073435; E-mail: zenufatee@ yahoo.com; asnasara@hotmail.com

Received: 07 September 2016/Accepted: 20 September 2016/ Published: 29 September 2016

\begin{abstract}
Reference ranges (RR) or Reference Intervals (RIs) are very important values for accurate interpretation of clinical laboratory test results. Any test result that is not accompanied by a valid RR value is less informative and may not be interpreted correctly. However, reference values of most analytes for Nigerian population are not readily available. The present study aims at establishing reference values of Serum Leptin and C-Peptide for Dutse, Jigawa State. In a cross sectional study, eighty (80) reference individuals were recruited. Serum Leptin and C-Peptide were analysed using ELISA methods. Following an accepted guideline, population specific reference intervals were established for these analytes and found to be $3.13 \mathrm{ng} / \mathrm{mL}$ to $14.09 \mathrm{ng} / \mathrm{mL}$ for Leptin and $0.56 \mathrm{ng} / \mathrm{mL}$ to $5.64 \mathrm{ng} / \mathrm{mL}$ for C-Peptide, respectively. Populations sharing similar physical and socio-economic characteristics may adapt these intervals if validated and considered suitable for their laboratory methods.
\end{abstract}

Keywords: reference ranges; Leptin; C-Peptide; ELISA; Dutse; Nigeria

\section{Introduction}

By definition, Reference Range (RR) for a particular measurement is defined as Mean $\pm 2 \mathrm{SD}$ and is the predictive interval between which $95 \%$ of values of a reference group falls into, in such a way that $2.5 \%$ of the time a sample value will be less than the lower limit of this interval, and $2.5 \%$ of the time it will be larger than the upper limit of this interval, whatever the distribution of these values (Stephen et al., 2008).An RR "is an interval that, when applied to the population serviced by the laboratory correctly includes most of the subjects with characteristics similar to the reference group and excludes the others" (Ceriotti, 2007). Methods for establishing reference ranges are mainly based on assuming a normal distribution (Sterne and Kirkwood, 2003) or a log-normal distribution (Patrick et al., 1992), or directly from percentages of interest (Winkle et al., 1979). In this part of the world, Leptin and C-peptide are biochemical analytes that are new and have potentials of being introduced into the routine investigations for improvement of patient care. Therefore their RRs values needs to be established for accurate test results interpretation. Methods for establishing these ranges are expensive and often difficult to perform (Alex et al., 2010), as such most laboratories depend on RRs that have been reported by the manufacturer or as established by another laboratory. For example, a survey of 500 
laboratories in 2001 by College of American Pathologists (CAP) found that 390 laboratories (78\%) adopted manufacturers' values for reference intervals (Friedberg et al., 2007).

In the above mentioned survey, 163 laboratories conducted an internal study of healthy subjects to establish reference intervals. Of these laboratories, about one half tested between $21-50$ samples and one quarter tested more than 100 samples. Methods for verifying reported RRs for adoption are relatively more simple studies and require only 20 healthy subjects to recruit (CLSI, 2008). However, it has been recommended that RRs be established for each and every Population, community and/or laboratory (Alex et al., 2010) becausethere are some biological differences in serum analytes levels of populations as a result of several factors including ethnic, racial, socio-economic and/or physical (El-Hazmi and Warsy, 2001).

Leptin is a $16 \mathrm{KDa}$ protein hormone that plays a key role in regulating energy intake and energy expenditure, including appetite and metabolism (Tracy et al., 2002). It is a hormone made by adipose cells that helps to regulate energy balance by inhibiting hunger. The biological effects of leptin action suggest its potential diagnostic and therapeutic utility in a variety of pathologic states, including obesity, diabetes and their comorbid diseases (Martins, 2006).

C-peptide is a short 31-amino-acids polypeptide that connects insulin's A-chain to its B-chain in the proinsulin molecule (Wahren et al., 2000). Patients with diabetes mellitus may have their C-peptide levels measured as a means of distinguishing type 1 diabetes from type 2 diabetes or Maturity Onset Diabetes of the Young (MODY) (Jones and Hattersy, 2013). C-peptide and insulin are secreted in equimolar amounts; however, C-peptide does not undergo significant hepatic extraction but is renally eliminated and therefore persists longer in the peripheral circulation. Thus, C-peptide has longer half-life (> 30 minutes) and less fluctuation serum levels compared to insulin (5 minutes half-life) (Rubenstein et al., 1969). Hence, measurements of C-peptide more accurately reflect pancreatic insulin secretion rates than insulin (Clark, 1999). Moreover, C-peptide concentration is independent of exogenous insulin and is not subject to interference from insulin auto-antibodies induced by insulin therapy (Schultess et al., 2009). However, this study aims at establishing reference ranges of serum Leptin and Serum C-Peptide levels for the inhabitants of Dutse, North-West Nigeria.

\section{Materials and Methods}

The study was conducted in Dutse, Jigawa State, North-West Nigeria. A total of eighty (80) reference subjects were recruited. These included individuals of both sexes (forty adult males and forty adult females), chosen from Dutse, Jiagawa state, North-West Nigeria. The subjects were selected using a direct method as described by the United States National Committee on laboratory Standards (NCCLS) Guidance Document C28A2. Accordingly, for most analytes, the lower and upper reference limits were assumed to demarcate the estimated $2.5^{\text {th }}$ and $97.5^{\text {th }}$ percentiles of the underlying distribution of values (Sasse et al., 2000). Ethical approval for the study was given by the Ethics and Research Committee of the Rasheed Shakoni Specialist Hospital, Dutse, Jigawa state. Informed consent was obtained from each subject prior to the commencement of study. From each selected subject, a total of five millilitres $(5.0 \mathrm{ml})$ of venous blood specimen was collected into a sterile vacutainer and allowed to clot at room temperature $\left(25^{\circ} \mathrm{C}\right)$. Each sample was centrifuged at 300r.p.m. for five (5) minutes and the clear unhaemolysed sera were harvested and rapidly kept frozen at $-20^{\circ} \mathrm{C}$ until analysed for serum Leptin and C-peptide levels, respectively.

Serum Leptin was estimated using the leptin ELISA Kit (WKEA Med Supplies Company, China, a commercially prepared kit based on Sandwich Principle, as developed by Engvall et al.(1971).Serum C-Peptide was measured by C-Peptide ELISA kit from Monobind Inc, USA, based on Sandwich Principle, as modified by Wang et al. (2012).

Data entry and analysis were performed using MS Excel (2007) and Epi Info 7 (CDC, 2015). Reference intervals were determined using the methods described in the NCCLS guidelines (NCCLS 1992). The underlying assumption is that the 2.5 th and 97.5 th percentiles will contain $95 \%$ of the distributions of normal values in the reference population.

\section{Results}

Figures 1 and 2 display the Orgive of Leptin (ng) and C-peptide (ng/L) respectively of the eighty (80) reference individuals, while Table 1 summarizes the lower (2.5\%) and upper limits (97.5\%) of the two analytes. 


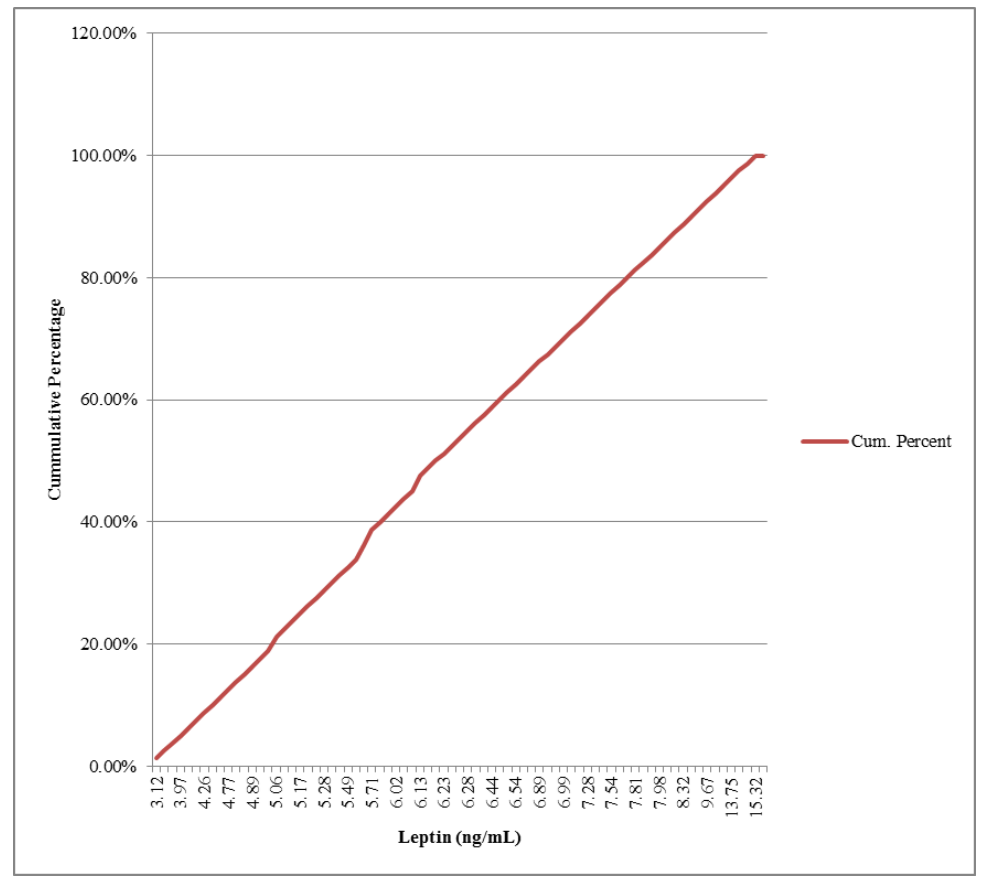

Figure 1. Serum Leptin $(\mathrm{ng} / \mathrm{mL})$ Orgive of the reference population.

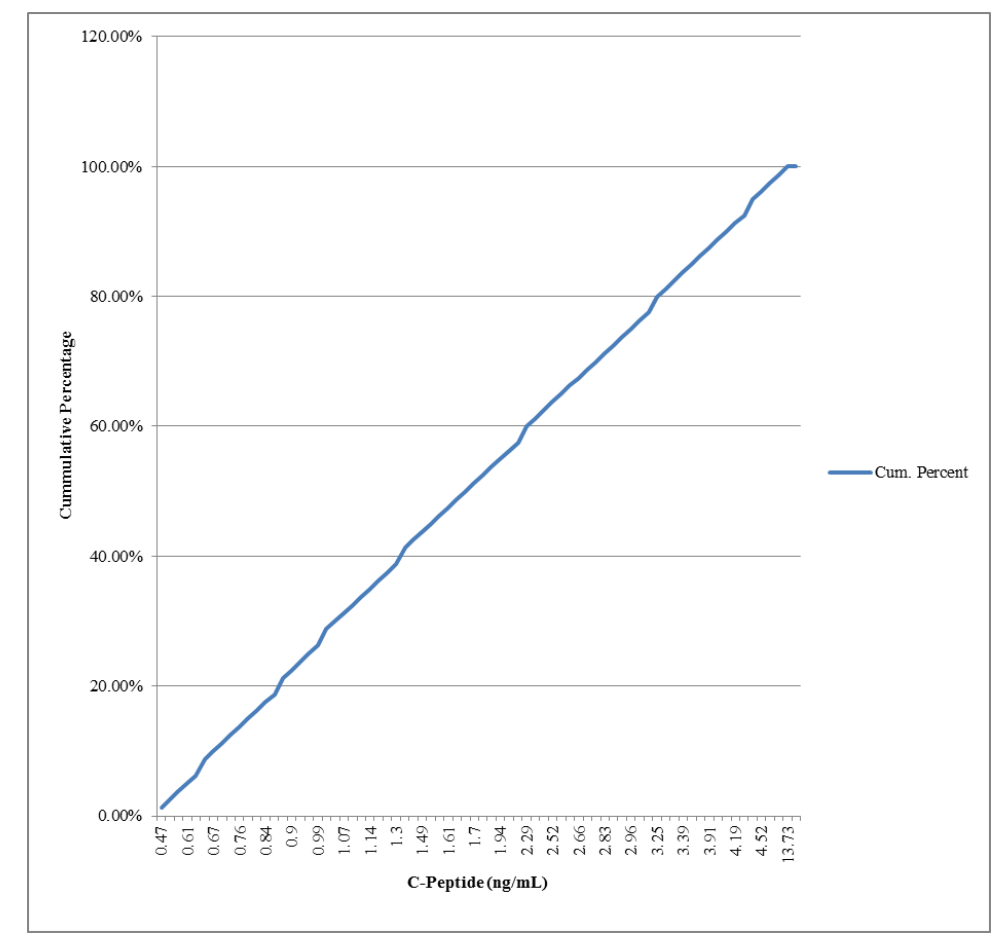

Figure 2. Serum C-Peptide (ng/mL) Orgive of the reference population.

Table 1. Reference values of Serum Leptin and C-Peptides in reference subjects (2.5 percentile lower limits and 97.5 percentile upper limits)

\begin{tabular}{lll}
\hline Variables & Leptin $(\mathbf{n g} / \mathbf{m L})$ & C-Peptide $(\mathbf{n g} / \mathbf{m L})$ \\
\hline Low & 3.13 & 0.56 \\
High & 14.09 & 5.64 \\
\hline
\end{tabular}




\section{Discussions}

Several researches have recommended the inclusion of serum Leptin (Abdelgadir et al., 2002; Sweeney, 2002; Van Gaal et al., 1999) and serum C-peptide (Jones and Hattersley, 2013) in the routine tests for management of diabetic and related patients. This prompted the need to establish reference ranges for these analytes. The present study established the lower and upper reference values of Serum Leptin and C-peptide for the studied population to help ininterpretation of laboratory results.

From the study, serum leptin lower and upper limit reference values were found to be $3.13 \mathrm{ng} / \mathrm{mL}$ and 14.09 $\mathrm{ng} / \mathrm{mL}$, respectively. Leptin reference values $(3.13-14.09 \mathrm{ng} / \mathrm{mL}$ ) agrees to some extent with $0.7 \mathrm{ng} / \mathrm{mL}$ (lower limit) and $18.3 \mathrm{ng} / \mathrm{mL}$ (upper limit) reported by Mayo Clinic US (1995 -2016). There was however, wide difference when compared with $8.95 \mathrm{ng} / \mathrm{mL}$ (lower limit) and 23.75 (upper limit) reported on the Spanish population (Teresa et al., 2015).

Similarly, Serum C-peptide lower and upper reference values were 0.56 and $5.64 \mathrm{ng} / \mathrm{mL}$ respectively. This is closely relatedto $1.1 \mathrm{ng} / \mathrm{mL}-4.4 \mathrm{ng} / \mathrm{mL}$ reported by Mayo Clinic US (1995 -2016). It however differs significantly (especially in the higher reference limit) from the $0.51 \mathrm{ng} / \mathrm{mL}-2.72 \mathrm{ng} / \mathrm{mL}$ reported by Global Diabetes Community, UK (2016).

It is clear from the present study that it is important to establish reference values that are applicable to specific community/laboratory instead of adopting a reference value that is meant for another different community/laboratory. This is because, reference values as a measure of physiological function may be affected by several factors that varies from population to population or from one community to another in relation to several variables including diet, socio-economic conditions, genetics and physical environment; and to a large extent the laboratory method(s) for the estimation of such analyte (ADA, 2015).This further buttressed the statement of Alex et al. (2010).

\section{Conclusions}

The reference values generated from this study can be used in Jigawa and its environs for proper interpretation of laboratory result of Leptin and C-Peptide in clinical management of diabetes and other related illness. It can also serve as a guide during some other health related activities such as screening population for diabetes etc. Populations sharing similar physical and socio-economic characteristics may adapt these intervals if validated and considered suitable for their laboratory methods.

\section{Conflict of interest}

None to declare.

\section{References}

Abdelgadir M, M Elbagir, M Eltom, C Berne and B Ahre'n, 2002. Reduced leptin concentrations in subjects with type 2 diabetes mellitus in Sudan. Metabolism, 51:304-306.

American Diabetes Association (ADA), 2015. Standards of medical care in Diabetes. "Diabetes Care, summary of revision" http://www.diabetes.org/diabetescare. DOI: 10.2337/dc14- SO14 (Accessed 03 Jun, 2016), 37:14-64.

Alex K, B Claudiu and WS David, 2010. Establishing reference intervals for clinical laboratory test results. Am. J. Clin. Pathol., DOI:10.1309/AJCPN5BMTSF1CDYP

Ceriotti F, 2007. Prerequisites for use of common reference intervals. Clin. Biochem. Rev., 28:115-121.

Clark PM, 1999. Assay for Insulin, Proinsulin and C-Peptide. Ann. Clin. Biochem., 36: 541 - 564.

Clinical and Laboratory Standards Institute, 2008. Defining, Establishing, and Verifying Reference Intervals in the Clinical Laboratory; Approved Guideline. Third Edition. CLSI document C28-A3. Wayne, PA: Clinical and Laboratory Standards Institute; 2008.

El-Hazmi Mohsen AF and S Warsy Arjumand, 2001. Normal reference values for haematological parameters, red cell indices, $\mathrm{HbA} 2$ and $\mathrm{Hb} \mathrm{F}$ from early childhood through adolescence in Saudis. Annals of Saudi Med., 21:165-169.

Engvall E and P Perlman, 1971. "Enzyme-Linked Immunosorbent Assay (ELISA). Quantitative assay of immunoglobulin G”. Immunochemistry, 8: $871-874$.

Jones AG and AT Hattersley, 2013. The clinical utility of C-Peptide measurement in the care of patients with diabetes. Diabetic Medicine, 30: 803-817.

Martin A. Crook, 2006. Clinical Chemistry and Metabolic Medicine. Seventh Edition. Edward Arnold London. 
Mayo Clinic, 1996-2016. Interpretive Handbook. Mayo Foundation for Medical Education and Research. http://www.mayomedicallaboratories.com/interpretive-guide/?alpha=C\&unit_code=8804.

National Committee for Clinical Laboratory Standards, 1989. Clinical Applications of Flow Cytometry: Quality Assurance and Immunophenotyping of Peripheral Blood Lymphocytes.: Proposed Guideline. NCCLS Document H42-P. Villanova, PA: NCCLS:

Patrick R, 1992. Estimation, reference ranges and goodness of fit for the three-parameter log-normal distribution. Ststistics in Medicine. Volume 11, Issue 7, Pages 897 - 912. John Wiley \& Sons, Ltd.

Rubenstein AH, JL Clark, F Melani and DF Steiner, 1969. Secretion of proinsulin C-peptide by pancreatic beta cells and its circulation in blood. Nature, 224: 697-699.

Sasse Edward A, T Doumas Basil, D'Orazio Paul, H Eckfeldt John, A Evans Susan, A Graham Gary, L Myers Gary, J Parsons Patrick and V Stanton Noel, 2000. How to Define and Determine Reference Intervals in the Clinical Laboratory Approved Guideline Second Edition. NCCLS Document C28-A2.; 20(13)

Schultess J, Cv Duren, M Martens, M Costa, T LIop, T Marti, M Eppinger, M Hausmann, W Krack and J Dhein, 2009. Diagnostic performance of the ARCHITECT C-Peptide immunoassay. Clin. Chem. Lab. Med., 47: $834-841$.

Stephen K. Bangert, William J. Marshall, Marshall and William Leonard, 2008. Clinical biochemistry: metabolic and clinical aspects. Philadelphia: Churchill Livingstone/Elsevier. ISBN 0-443-10186-8. CS1 maint: Multiple names: authors list (link)

Sterne J and BR Kirkwood, 2003. Essential medical statistics. Oxford: Blackwell Science. ISBN 0-86542-871-9.

Sweeney G, 2002. Leptin signaling. Cellular Signalling. 14: 655-663

Teresa G, G Auxiliadora, G Pilar, A M. Teresa, RA Fernando and RB José, 2015. Leptin Reference Values and Cutoffs for Identifying Cardiometabolic Abnormalities in the Spanish Population. Rev. Esp. Cardiol., 68: 672-679.

Tracy RP, RN Lemaitre and BM Psaty, 2002. Relationship of C-reactive protein to risk of cardiovascular disease in the elderly." Circulation, 5:1142-1145.

LF Van Gaal, MA Wauters, IL Mertens, RV Considine and IH De Leeuw, 1999. Clinical endocrinology of human leptin. Int. J. Obes. Relat. Metab. Disord., 23 (suppl. 1): 29-36.

Wahren J, K Ekberg, J Johansson, M Henriksson, A Pramanik, BL Johansson, R Rigler and H Jornvall, 2000. Role of C-peptide in human physiology. Am. J. Physiol. Endocrinol. Metab., 278: E759-68.

Wang L, NF Lovejoy and DL Faustman, 2012. Persistence of prolong C-peptide production in Type 1 Diabetes as measured with an ultrasensitive C-peptide assay. Diabetes Care, 35: 465 - 70.

Winkle P and BE Statland, 1979. Reference values In: Clinical Diagnosis and Management by Laboratory Methods, Henry JB (ed). WB Saunders, Philadelphia, pp 29-52. 